\title{
SECULAR AND CHRISTIAN RESPONSES TO CORINTHIAN FAMINES
}

\author{
Bruce W. Winter
}

There is a unique set of first century $A D$ inscriptions from Corinth erected to one of its leading citizens, Tiberius Claudius Dinippus. ${ }^{1}$ They record the high public offices which he held in that city during the formative period of the Christian church there. ${ }^{2}$ From the extant epigraphic evidence no other first century benefactor in Corinth could have laid claim to the honour bestowed upon Dinippus, for not only the Council but at least ten of the twelve Tribes comprising the administrative divisions of that city, erected similar inscriptions in honour of him. ${ }^{3}$ What gave rise in that city to this unique, spontaneous display of public honour for this Corinthian benefactor?

The clue may well lie in the fact that Dinippus was three times curator of the grain supply, curator annonae. ${ }^{4}$ The traditional ascending order of importance of honorary public

${ }^{1}$ A. B. West, Corinth: Results of Excavations conducted by the American School of Classical Studies at Athens 1896-1926 (Cambridge Mass., 1931) VIII/II no. 86-90 [cited Corinth], J. H. Kent, ibid. 1926-50 (Princeton, 1966) VIII/III, no. 158163. J. Murphy-O'Connor, St. Paul's Corinth: Texts and Archaeology (Wilmington, M. Glazier 1983) did not include the inscriptions to Dinippus in his collection.

2'duovir, duovir quinquennalis, augur, priest of Britannic Victory, [military tribune of Legios VI] Hispanenesis, chief engineer, curator of the grain supply three times, [agonothetes] of the Neronea [Caesarean and of the Isthmian and Caesarean games]', Kent, Corinth no. 158.

${ }^{3}$ As the only difference between these eleven Latin inscriptions is in the abbreviations of the various leading offices he filled, it is right to regard this great show of gratitude as occurring at the same time as all are listed in the same order. Great benefactors of the second century to whom Corinthian inscriptions were erected were the Athenian, Herodes Atticus, and the Epidarian, Cornelius Pulcher. The latter held similar offices to Dinippus including curator annonae, $\varepsilon \pi \iota \mu \epsilon \lambda \eta T\rangle$ s $\epsilon \dot{\theta} \theta \eta \nu l a s, I G$ IV 795 and B. D. Merit, Corinth: 1896-1927 (Cambridge Mass., 1931) VIII/1. no. 76. He was honoured in other inscriptions, ibid. no. 80-83. In no. 76, 80-1 the character of the letters are the same. no. 82-3 supported statues erected at the same time. They were not however all erected on the same occasion, see West, Corinth no. 71-2, nor with the same wording as in the case of Dinippus.

${ }^{4}$ In West, Corinth no. 92 and Kent, Corinth no. 161, the fragments do not preserve the record of his term as the superintendent of the grain supply but it can be assumed, given its mention in the other inscriptions cited in $n .1$. 
offices would normally have placed the Corinthian magistrates below the president of the Games. ${ }^{5}$ In the inscriptions to Dinippus however curator annonae was placed next to the most prestigous office viz. the President of the Games. In the minds of the Council and the Corinthian Tribes which constituted the administrative districts of Corinth, the alleviation of the city's needs on three occasions was a matter of enormous importance. Although during the first and second century $\mathrm{AD}$ others in Corinth accepted the office of curator annonae, no other person is known to have held it more than once. ${ }^{6}$ When it was held by Boulargos of Samos three times in the mid-third century BC it indicated a chronic dearth of food. ${ }^{7}$ As this crucial office was only filled in times of famine, it indicates a series of intermittent grain shortages in Corinth.

The purpose of this paper is to investigate (I) famines in the East, especially Corinth, in the early years of the Christian church during the Principates of Claudius and Nero and the reasons for them; (II) the social dislocation caused by famine or fear of famine, and the Christians' reaction with its possible nexus with 'the present dudykr' of 1 Corinthians 7:26; (III) the Corinthians' official response to this problem with the appointment of Ti. Claudius Dinippus as curator of the grain supply and by way of contrast Paul's response in 1 Corinthians 7:27ff. with his seeming indifference to the 'have nots' of 1 Corinthians 11:21, 34 and (IV) the possible reason for the different responses of the Jersualem and Corinthian churches to food shortages.

${ }^{5}$ In Corinth the games were of such importance that its president took precedence in status over the magistrates: J. Wiseman, 'Rome and Corinth I', ANRW II.7.1 (1979) 500.

${ }^{6}$ For holders of the office in the first and second centuries AD apart from Dinippus and Cornelius Pulcher see Kent, Corinth VIII/III no. 164 (70-100), 170 (c. 125), 177 (164), 127 (late second century), and 169, 188, 227, 234-6, 238, Merit,

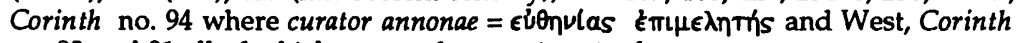
no. 83 and 91 all of which are too fragmentary to date.

${ }^{7} \mathrm{P}$. Garnsey, Famine and Food Supply in the Graeco-Roman World Responses to Risk and Crisis (CUP 1988) 14 citing SEG 336. 


\section{Famines in the East in the Forties and Fifties}

It is important in discussing 'famine' in the Principates of Claudius and Nero to note that the term reflects the situation created by grain shortages which resulted in a steep rise in its price on the market through a crop failure or a regional dearth from a succession of crop failures. ${ }^{8}$ 'Even in richest corn-growing provinces...cases of local famine were frequent', and the reason for this is that many of the major cities in the East were located in agricultural areas which were not capable of fully supporting them with grain. ${ }^{9}$ The planting of the Roman colony of New Corinth in 46 B.C. was not the result of a feasibility study undertaken to assess the adequacy of the agricultural infrastructure. ${ }^{10}$ In addition Corinth's commerce had greatly expanded in the intervening one hundred years.

What extant evidence is there for grain shortages in the East during the forties and fifties? Eusebius states 'In his time [Claudius'] famine seized the world'.11 When Pliny comments that the Nile once rose to an unprecedented height of eighteen cubits and that if it rose to sixteen a famine ensured, he is referring to record flooding and the subsequent famine which followed in the mid-forties. ${ }^{12}$ There is also non-literary evidence of an acute crop failure in Egypt from the autumn of

${ }^{8} \mathrm{M}$. Jameson, 'Famine in the Greek World,' in P. Garnsey and C. R. Whittaker (edd.),Trade and Famine in Classical Antiquity (CPS Supp. 8, 1983) 6, speaks of 'the temporary shortage of grain in the Greek cities' when comparison is made with the vast famines in China and Africa experienced this century. F. F. Bruce, The Acts of the Apostles (London, Tyndale Press 1952) 239 comments that 'famine' is not perhaps the most appropriate term, but that 'dearth' should be used.

${ }^{9} \mathrm{M}$. Rostyovtzeff, The Social and Economic History of the Roman Empire II (Oxford, Clarendon Press 1957) 600.

10'Another Caesarian colony founded for economic or social reasons was the most celebrated of them all, Corinth ... Its coloni were freedmen for the most part .. . and this, taken in conjunction with its siting shows that the colony could not have been agrarian. It was manifestly intended to revive the mercantile glories of the city that Mummius had destroyed in 146.' E. T. Salmon, Roman Colonization under the Republic (London, Thames and Hudson 1969) 135.

${ }^{11}$ E.H. II viii.

${ }^{12}$ Natural History V 58, XVIII 168. K. S. Gapp, "The Universal Famine under Claudius', HTR 28 (1935) 259. 
AD 45 or 46 to the following spring of 46 or $47 .^{13}$ This is seen in the inability of taxpayers to meet the poll, pig and dyke taxes

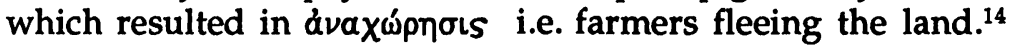
In P. Mich. 594 (Sept.-Oct., 51) there is a list of arrears for the above taxes of 1,222 people who defaulted in $45 / 46$ increasing to 1,678 the following year and declining in $47 / 48$. In 50/51 there are still defaulters. It has been calculated that more than half of the male population in Philadelphia in Egypt had defaulted. ${ }^{15}$ Other papyrological evidence also presents the same picture. SB 7461(AD 45) indicates that taxpayers were unable to meet their obligations and fled the city to another Nome to which a request was made for them to be brought back under armed guard. ${ }^{16}$ In spite of Egypt's reputation as a grain bowl for Rome and the East, its inhabitants could suffer financial hardship and shortage of food. ${ }^{17}$

There was also the well-known Judaean famine $c .46$ or 47 when Tiberius Julius Alexander, the apostate Jew and nephew of Philo of Alexander was procurator from c. AD 46-48. Helena, Queen of Adiabene, visited Jerusalem to find inhabitants dying and sent to Cyprus for dried figs and to Egypt for grain. ${ }^{18}$ The precautions taken by the Christians as a result of the prophecy of Agabus in Antioch saved the Jerusalem Christian community. ${ }^{19}$ This famine extended to all of Syria

${ }^{13}$ Gapp, op. cit. 259-60.

14 Philo records the particularly cruel treatment handed out by a tax-collector to those next of kin when the debtor fled, Spec. III 159-63.

${ }^{15} \mathrm{G}$. M. Browne, Documentary Papyri from the Michigan Collection, X (ASP 6; Toronto, 1970) 64-7. For subsequent problems see $P$. Cornell 24 (AD 56) and $P$. Ryl. 595 (AD 54-5) and discussion by J. F. Oates, 'Fugitives from Philadelphia', Essays in Honour of C. Bradford Welles (ASP I; New Haven, 1966) 87-95 who assesses the Egyptian economic crisis and cautions against projecting Egypt's problems onto the whole empire without external evidence.

${ }^{16} \mathrm{O}$ the use of soldiers for collecting taxes see H. I. Bell, 'The Economic Crisis in Egypt under Nero', JRS 28 (1938) 5-6.

${ }^{17}$ North Africa was the predominant supplier of grain for Rome's insatiable need to support those entitled to the monthly grain dole in the imperial city, see Garnsey, Famine and Food 255.

18 Browne, op. cit 260-1.

${ }^{19}$ Acts 11:27-30, Eusebius, E.H.. I. viii. Gapp, loc. cit. 26 dates the famine to $\mathrm{AD}$ 46 or 47 restricting the period to Tiberius Julius Alexander's procuratorship of Judaea. J. Jeremias, Jerusalem in the Time of Jesus: An Investigation into the Economic and Social Conditions during the New Testament Period (ET; Philadelphia, Fortress Press 1969) 142-3 dates it on the basis of a crop shortfall 
because of the shortage of grain. It was in fact widespread but the effect was not felt instantaneously throughout the empire. ${ }^{20}$ The prophecy referred to a worldwide dearth of

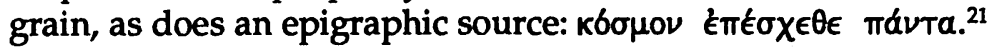

$P$. Garnsey notes that there were 'flooding and food shortages which affected numerous states in Greece...in the 40's and $50^{\prime} \mathrm{s}^{\prime}{ }^{22}$ Of this period Eusebius refers to $\lambda \ell \mu \mathrm{s}$ кaTd Tiेv 'Eגáda when the price of grain was extremely high. ${ }^{23}$ Suetonius verifies that the food shortages of AD 51 were the result of crop failure, sterilitas but does not specify the location. ${ }^{24}$ The epigraphic evidence relating to Dinippus clearly shows that at least in Corinth there were grain shortages three times during the reign of Claudius and the early Principate of Nero. ${ }^{25} \mathrm{~J}$. Wiseman places at least one such occasion when Dinippus was curator annonae during Gallio's proconsulship of Achaea c. AD $51 . .^{26}$

In addition to crop failures there was the constant pressure from Rome to feed with the corn those vast numbers of

in 47-8 aggravated by the sabbath year. C. J. Hemer, 'Observations on Pauline Chronology', in D. A. Hagner and M. J. Harris (edd.),Pauline Studies: Essays presented to Professor F. F. Bruce on his 70th Birthday (Exeter, Paternoster Press 1980) 5-6, suggests a slightly earlier period-AD 45-6.

${ }^{20}$ Orosius, Hist. VII 6.17 refers to a famine in the tenth year of Claudius' reign which began in AD 41. Eusebius states that there was one in the eighth or ninth year. Both witnesses may be correct in their dating given the rolling food shortages which were experienced during the Principate of Claudius.

${ }^{21}$ W. H. Waddington, Inscriptions grecques et latines recueillies en Grèce et en Asie Mineure V (1870) no. 1192 l. 6 contra E. Schürer, The History of the Jewish People in the Age of Jesus Christ (175 BC -AD 135), I (Edinburgh, T.\&T. Clark 1973) $457 \mathrm{n} .8$ treats the view of a world-wide famine as improbable. However contemporary commentators from their vantage point regarded it as such because there were a series of on-going shortages.

22 There were problems in Acraephia, Greece in the forties, IG VII 2712. Only the benefactions of one man helped the city to survive and thrive, J. H. Oliver, 'Epaminondas of Acraephia' GRBS 12 (1971) 233-6. See discussion also by Garnsey, Famine and Food 261.

${ }^{23}$ Eusebi Chronicorum II (Berlin, 1886) 151.

${ }^{24}$ Claudius 18 'a scarcity of grain because of long-continued droughts'.

${ }^{25}$ For discussion, including the terminus ad quem of the honorary public offices of Dinippus, see pages 98-9.

${ }^{26}$ Wiseman, 'Rome and Corinth I' 505. See also West, Corinth, 70 and V. P. Furnish, 'Corinth in Paul's time: What can Archaeology tell us?', Biblical Archaeology Review.15 (1988) 19 who notes 'According to inscriptional evidence uncovered by archaeologists, a severe famine occured in 51 A.D.'. 
its inhabitants who were traditionally entitled to the monthly corn dole without any means test whatsoever. It was granted on the grounds of their citizenship and residence in the imperial capital. ${ }^{27}$ Short falls in the harvest aggravated the problem for cities in the East, as the failure of the emperor to meet the needs of Rome was of such political consequence that it had of necessity first claim on existing supplies. Thus, a second century emperor reminded the city of Ephesus 'bearing in mind the necessity that first the imperial city should have a bounteous supply of wheat procured and assembled for its market' ${ }^{28}$

\section{The Social Dislocation caused by Famine}

A second century AD Ephesian inscription notes in its preamble the expected response to famine. 'Thus it happens at times that the populace is plunged into disorder and riots' ${ }^{29}$ Other sources also observe that there were always accusations by the mob of mismanagement, or profiteering by the corn-dealers and as a result, 'grave social disturbances occurred riots and demonstrations were common'.$^{30}$ Seneca, writing of the problems in Rome in AD 40-1, says

we were threatened with the worst evil that can befall men even during a siege - the lack of provisions...[and Gaius's policies were pursued] very nearly at the cost of the city's destruction and famine and the general revolution that follows famine. ${ }^{31}$

Of problems in AD 32 Tacitus wrote 'the excessive price of grain all but ended in rioting [in Rome] and large demands were made for several days in the theatre' ${ }^{32}$ Apollonius of Tyana observes such a rampage when he arrives in Aspendus of

\footnotetext{
${ }^{27}$ G. Rickman, 'The Corn Distribution', The Corn Supply of Ancient Rome (Oxford, Clarendon Press 1980) ch. 7 and Garnsey, Food and Famine $198 \mathrm{ff}$.

28 I. Ep. 215, ll. 1-3 cited Garnsey, Famine and Food 255 and see also 231-2.

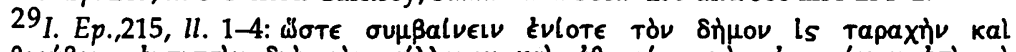

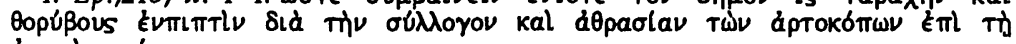
dyopd oráoewv.

30 See Rostyovtzeff, op. cit. 146.

31 Seneca, Breo. vit. 18.5 cited Garnsey, Famine and Food 222.

32 Annals 6.13
} 
Pamphylia where the population was forced to eat vetch during the Principate of Tiberius.

an excited crowd of all ages had set upon the chief magistrate and was lighting a fire to burn him alive even though he was clinging to the statue of the emperor. The chief magistrate plucked up courage and said 'So-and-so and So-and-so' naming several 'are to blame for the famine that has arisen, for they have taken away the grain and are keeping it in different parts of the country.' A hue and cry thereupon arose among the Aspedians to make for these men's estates. ${ }^{33}$

Apollonius rescued the magistrate by persuading the speculators to release grain to the citizens.

P. Garnsey observes that the fear of famine rather than famine itself was enough to send people on the rampage, as in $57 \mathrm{BC}$ or $\mathrm{AD} 51^{\prime} .{ }^{34}$ Dio Chrysostom in c. AD 70-80 encountered such a mob in his home town. They had attempted to storm his estate because of the rise in the price of grain and the allegations that hording was being practised. The crowd was rebuked by him the following day in the assembly as he reminds them of their intention to stone them [he and rich fellow citizens] and burn their houses, with a view to consuming in one conflagration if possible them and their children and their wives'. He argues that they are reacting irrationally because the cost of grain had risen to a price comparable to that in other places and 'it is not so high as to make you desperate' ${ }^{35}$ 'Hungry people do not listen to reason' Seneca was to observe, and his nephew, Lucan the poet said, 'The grain supply provides the mainsprings of hatred and popularity. Hunger alone sets cities free, and reverence is purchased when rulers feed the lazy mob: a hungry population knows no fear' ${ }^{36}$

Tacitus declared that AD 51 was an 'ominous' year. 'There were earthquakes and subsequent panic in which the

${ }^{33}$ Philostratus, The Life of Apollonius of Tyana I xv and comments by C. P. Jones, The Roman World of Dio Chrysostom (Cambridge Mass. and London, Harvard University Press 1978) 21 and G. Anderson, Philostratus: Biography and Belles Lettres in the Third Century AD (London and Sydney, Croom Helm 1986) 191 on the reliability of Philostratus and his sources.

${ }^{34}$ Garnsey, Famine and Food 31.

${ }^{35}$ Or. 46:10-12 citation \#11 and discussion by C. P. Jones, 'Riot at Prusa', op. cit. ch. 3 and for the dating of the oration 134.

${ }^{36}$ On the Shortness of Life, xviii 5 and Pharsalia, III 55-58. 
weak were trampled under foot'. In addition, he notes, there was once again a shortage of corn and, as a consequence, famine. He records that all this was construed as 'a supernatural warning ${ }^{\prime}{ }^{37}$

1 Corinthians 7:25 notes the 'present' ${ }^{38}$ d $\nu$ d $\gamma \kappa \eta$ being experienced in Corinth. Was this a reference to dislocation in the city's life caused through a series of acute grain shortages and the attendant social unrest? The language used suggests that Corinth was presently experiencing yet another famine with the usual dislocation, ${ }^{39}$ and this was seen by the Christians as the beginning of the eschatological birthpangs. There was a nexus was between such catastrophes and these birthpangs in the early church as Mark records 'there will be earthquakes in various places, there will be famine; this is but the beginning of the birthpangs' ${ }^{40}$ The prophecy of Agabus of a famine was fulfilled and from the time of the worldwide food shortage under Claudius there was a heightened expectation of the parousia as witnessed in the Thessalonian letters of Paul. ${ }^{41}$

The discussion in 1 Corinthians 7:1ff. on how to deal with the present d'vá $\gamma \kappa \eta$ arose out of two specific questions which the Corinthian church asked Paul concerning marriage. ${ }^{42}$ They sought advice as to whether they should have further

37. Tacitus, Annals 12.43.

${ }^{38} \mathrm{H}$. Conzelmann, 1 Corinthians, (ET; Philadelphia, Fortress Press 1975) $132 \mathrm{n}$.

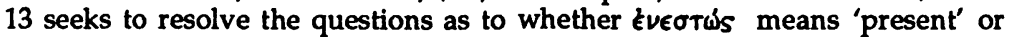
'impending' by suggesting 'imminent'. He argues that in some passages it means 'present' and in others 'immediately impending'. He notes that 1 Cor. 3:22, Rom. 8:38 and Gal. 1:4 refer to 'present'. He observes that 'each particular instance must be interpreted according to its context' and therefore accepts "impending"

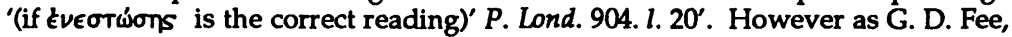
The First Epistle to the Corinthians (Grand Rapids, Eerdmans 1987) 329 argues that "the term "present" invariably means what is already present in contrast to what is yet to come' and supplies supporting evidence.

39 Thucydides, III. 82:2, 85:2, speaks of situations where cities were forced to

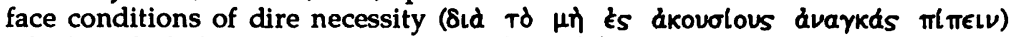

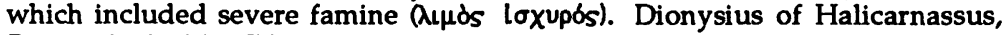
Roman Antiquities IX 3-4 records an extreme situation with 'great famine in the city, and otárs, and perplexity (ánXavla) as to what should be done'.

$40 \mathrm{Mk13:8}$ of. Mt 24:7-8.

41 Acts 11:28, 1 Thess. 4:13 -5:11, 2 Thess. 2:1-12.

${ }^{42}$ On the use of $\pi \epsilon \rho l \delta \notin$ for responding to matters in letters see $B G U 1141$ and $C$.

E. Faw, 'On the Writing of First Thessalonians', JBL 71 (1952) $221 \mathrm{ff}$. 
children. ${ }^{43}$ Abstention from sexual intercourse in marriage would have been the only acceptable means of birth control for Christians (7:1).44 They also asked whether a betrothed couple whose relationship was officially a binding one should still proceed to consummate the marriage $(7: 25) .{ }^{45}$ It is possible therefore to make sense of the discussion in 1 Corinthians 7:25ff. in the light of a local famine with the uncertainty brought by it to the lives of all its citizens and the supernatural significance attached to it.

Paul's arguments in vv. 29 and 31 were based on the conviction that 'the appointed time had grown short' and 'the form of the world was passing away', the passing of which had as its prelude earthquakes and famines. ${ }^{46}$ The early Christians saw these dislocations as eschatological signs.

43 The Corinthians raised the question 'Should a man "touch" i.e. have sexual intercourse with his wife?' In Greek marriage terminology 'woman' referred to a 'wife' and the verbs 'to touch' and 'to have' were euphemisms for sexual intercourse. For the use of $r u t$ for a wife in marriage contracts see BGU 1052 (13 BC) $l l .14,15$; 'wedded wife' ( (AD 66) $l .4$; 'wife' ( $\gamma u v$ ) for a woman who had lived in a recognized form of union but without a written contract 'has been living with him as his wife', and for the reference to a man's wife without the use of the pronoun as in 1 Cor. 7.1 see Plutarch, De tranquillitate animi 475B 'the adultery of your wife' (i)

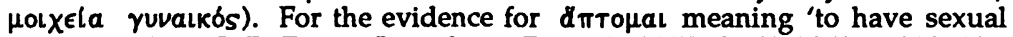
intercourse' see G. D. Fee, '1 Corinthians 7:1 in the NIV', JETS 23/24 (1980) 30714 with seven examples, and for further evidence also Plutarch, Pompey II 3 he

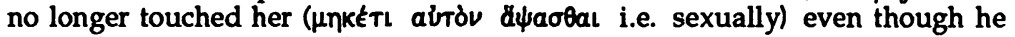
was still fond of her' a reference to a woman with whom he had had a longstanding sexual liaison. See also Fee, 310-11 for the evidence for 'let each man have his own wife' as a euphemism for sexual intercourse.

${ }^{44} \mathrm{On}$ the use of 'self-restraint', infanticide and abortion as the usual methods of contraception in the ancient world see L. P. Wilkinson, 'Population and Family Planning', Classical Atitudes to Modern Issues (London, William Kimber 1979) ch. 1 and especially 29ff. In the 'Little Apocalypse' of Mark 13 not being pregnant was a blessing for a woman because of the coming crisis, Mark 13:17, of. Luke 23.29.

${ }^{45}$ Fee, The First Epistle to the Corinthians 327.

${ }^{46}$ V. L. Wimbush, Paul the Worldly Ascetic: Response to the World and Selfunderstanding according to I Corinthians 7 (Macon, Mercer University Press 1987) pays no attention to the significance of 1 Cor. 7:25. He argues that Paul 'in general opted for a "worldly" model of existence that allowed them to "use" the world in pursuit of "the things of the Lord"', but has the unlikely suggestion that $\omega s \mu$ refers to an aristocratic urban spirituality, $83 \mathrm{ff}$. and 93 . 


\section{Official Secular and Christian Responses}

Roman officials in the provinces only on rare occasions intervened. For example, because of a severe winter and the loss of the harvest the Governor of the province of Galatia commanded the citizens and residents of Pisidian Antioch in AD 93 to declare within thirty days

how much grain each has and in what place, and how much he deducts for seed or for the year's supply of food for his household, and he shall make all the remaining grain availableit is most unjust for anyone to profiteer from the hunger of his fellow citizens, I forbid the price of grain to exceed one denarius per modius. ${ }^{47}$

This edict reflects an unusual situation in the East, with the Roman administration intervening in the affairs of the city only because it failed to resolve the problem itself. ${ }^{48}$ The East, unlike Rome, never set up a permanent administration for the grain supply. ${ }^{49}$ As A. R. Hands notes

No surplus was normally kept in hand to meet contingencies. And just because there were for every state a series of contingencies (not least on failure of the corn supply), each tended to live with a succession of financial crises. ${ }^{50}$

The corn supply and its price was a highly explosive issue and it was therefore 'a regular and highly important item

${ }^{47}$ F. F. Abbott and A. C. Johnson, Principal Administration in the Roman Empire, (New York, Russell and Russell 1926) no. 65a. This decree may well reflect the famine in Rev. 6.6 'And I heard a voice ... saying "A choenix of grain for a denarius ... and cheat not on the oil and wine."'

${ }^{48}$ Garnsey, Famine and Food 261 perhaps generalizes when he says There are thousands of inscriptions celebrating the generosity of local benefactors who gave grain ... or sold it cheap, contributed to funds for the purchase of extra stocks, and served as grain commissioners. The spirit of patriotic munificence was contagious'. There certainly is extant evidence to support this comment, but there were occasions when benefactors were not forthcoming to undertake such honorary public offices.

${ }^{49}$ Garnsey, Famine and Food 177. On the vast infrastructure Rome evolved for this purpose see G. Rickman, Roman Granaries and Store Buildings (CUP 1971).

${ }^{50}$ A. R. Hands, Charities and Social Aid in Greece and Rome (London, Thames and Hudson 1968) 39. 
on the agenda of the ekklesia' ${ }^{51}$ A time-honoured convention existed in the East during times of food shortages whereby one of its wealthy citizens was encouraged or pressurized into accepting the costly honorary public office of curator of the grain supply. .2

In Dio's oration to Prusa he records that the supervision of the market was undertaken by the election of men who were 'financially able', ${ }^{53}$ and who had not recently undertaken public office. ${ }^{54}$ There was a long history of the hoarding of grain by dealers and they, as part of the rich in the city, were also among those elected as its leaders to such public offices. ${ }^{55}$

The curator annonae sought to have grain sold at a reduced price and thereby manipulate the market in favour of the consumer. Because the markets were normally regulated on the basis of supply and demand, dumping grain had the immediate effect of depressing the price. H. W. Pleket notes Local power and prestige protected the city population against free interplay of economic factors. ${ }^{56}$ The technical term, mapdimparis, 'to sell at a reduced price', was used to describe this activity of a benefactor who sold grain to the citizens at substantially lower prices. The occurrence of this term is said to be 'almost always found during periods of dearth or famine'. ${ }^{77}$

${ }^{51} \mathrm{H}$. W. Pleket, 'Economic History of the Ancient World and Epigraphy: Some Introductory Remarks', Akten des VI. International Kongresses für griechische und lateinische Epigraphik (München, C.H. Beck'sche 1973) 247.

${ }^{52}$ For inscriptions recording benefactors operating as curator annonae see Hands, op. cit., documents no. 2 (330-325 BC), 6 (second century BC), 7 (c.150 BC), 12 (c. AD 42), 14 (early first century AD), 15 (first century AD), 23 (not earlier than AD 50) 29 (AD 100-150). These come from Greece or Asia Minor.

${ }^{53}$ They needed to have the resources to subsidize the price of corn as they had to be certified as being 'well to do', $\epsilon$ ŨTopol, in order to be eligible to perform a costly public office, e.g. BGU 18 (AD 169) $l$. 13.

${ }^{54} \mathrm{He}$ himself claimed to have performed more public offices than any other citizen in Prusa. On Dio's subsequent problems as a benefactor who sought to beautify his city see Jones, op. cit. ch. 12 .

${ }^{55}$ See the fifth century BC forensic speech in Lysias, Against the Corn-Dealers no. 22 at a trial of grain hoarders. On anti-speculation and the remedial law of Julius Caesar or Augustus lex Iulia de annona and the extension of it to Spain in the second half of the first century AD see Garnsey, Famine and Food 76-8.

56 Op. cit. 254.

57J. Triantaphyllopoulos, 'PARAPRASIS', Acta of the Fifth International Congress of Greek and Latin Epigraphy, Cambridge, 1967 (Oxford, Blackwells 1971) 65-9. 
There are instances where the curator annonae to his own financial benefit persuaded a benefactor to import grain in a time of famine and sell it cheaper than the market price. ${ }^{58}$ Thus for his benefaction this man from Rhodes was awarded citizenship and other customary honours by the Council and People as this inscription records:

having imported a quantity of wheat, and finding that the corn in the market was being sold at more than (?) drachmae, persuaded by the superintendent of the market, and wishing to please the People, sold all his corn cheaper than that which was being sold in the market: ${ }^{59}$

Manipulation of the market was not restricted to noncitizens. Rich citizens in the city were persuaded to subscribe to a fund for the purchase of grain. It was in the interests of the rich in a city to assist not merely from love of honour, but out of self-interest, knowing that the alternative would be rioting and plundering of their goods and stores. ${ }^{60}$ The rich were realistic to recognize that the tranquility of the city and their personal safety rested on the city securing grain at a reasonable price. As Hands comments, 'In Greek drama the claims of pity not infrequently urged upon the great and the wealthy are connected, not with the gods' pity for the poor as such, but with envy of the prosperous. ${ }^{\prime 61}$ There was always the need for the price of grain to be such that those who sold it were seen not to be speculating. "The public generosity of the wealthy was an institution devised by the rich in their own interests. As the grain stocks of the community were in their barns, they could time their release to suit themselves' ${ }^{62}$

What was expected of the person accepting the office of the curator annonae was that he himself would contribute because he was in effect agreeing to underwrite the cost of a

\footnotetext{
${ }^{58} \mathrm{D}$. Rathbone, 'The Grain Trade and Grain Shortages in the Hellenistic East', in P. Garnsey and C. R. Whittaker (edd.), Trade and Famine in Classical Antiquity (CPS Supp. 8; CUP 1983) 49.

${ }^{59}$ BMI 455 (150 BC).

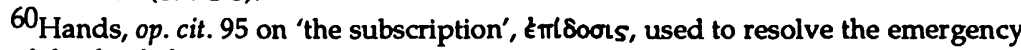
of the food shortage.

$61_{\text {Hands, op. cit. } 78 .}$.

${ }^{62}$ Garnsey, Famine and Food 272.
} 
reduction in the price of corn? To persuade others to give he would need to set an example. ${ }^{63}$

Dinippus of Corinth accepted the responsibility imposed on him by the office of curator annonae not once but on three occasions. West notes that his extensive benefactions indicate great needs in the city, and this furthermore points to the fact that he was a very wealthy and well known citizen of Corinth. ${ }^{64}$

When did Dinippus hold the various offices to which the inscriptions refer? He held the office of one of the chief magistrates, duoviri, who were elected annually and were

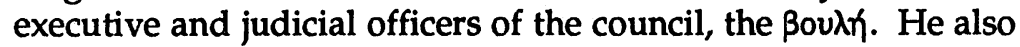
held this office for another term when the census was taken every five years, duoviri quinquennales, and the magistrates nominated new members of that council. Another office in this city was that of chief engineer of the Council, praefectus fabrorum, a position likely to have been exercised prior to the most senior position in rank of chief magistrate. Dinippus was President of the Games celebrated in AD 55 which would have involved him in the enormous expense of staging them, as well as personally bearing the cost of the constant entertainment of dignitaries. ${ }^{65}$ The president of the Games became the most senior in status. ${ }^{66}$ Because the curatores annonae were appointed only in times of need, A. B. West notes that it is possible that Corinth had a curator annonae on more than one occasion during the reign of Claudius' ${ }^{67}$ As has been noted, Greece was affected by famine from the middle to the end of

${ }^{63}$ Jones, op. cit. 19 and 166 n. 4.

${ }^{64}$ West, Corinth 73 who also cites the second century Epidaurian patron of Corinth, Cornelius Pulcher, and comments on both that 'their benefactions must have been extensive and the need great'.

${ }^{65}$ Plutarch, Quaes. convio. $723 \mathrm{~A}$ 'During the Isthmian games, the second time Sospis was president, I avoided the other banquets, at which he entertained a great many foreign visitors at once, and several times entertained all the citizens.'

${ }^{66}$ Wiseman, 'Rome and Corinth I' 497-500. See Epictetus, Discourse III.I.34 where $\alpha \gamma \omega \nu 0 \theta \in T / S$ is the most senior honorary public office having displaced in seniority the office of magistrate because of the enormous importance of the games. On this issue of rank and status see E. A. Judge, Rank and Status in the World of the Caesars and St. Paul (Christchurch, University of Canterbury Publications 1982).

67West, Corinth, 91. 
the forties and also in 51. J. Wiseman suggests that Dinippus may have been curator annonae during that year. ${ }^{68}$ There is no extant evidence of any other holder of this office during the late $40 \mathrm{~s}$ and $50 \mathrm{~s}$. The precise dates when he held the office are not certain, although it would have been before the Games of 55. It has been suggested that Dinippus held the office of magistrate either in $52 / 3$ or $57 / 8 .{ }^{69}$ The seniority of the presidency of the Games held in 55 over the former position makes the earlier date of $51 / 52$ more likely. ${ }^{70}$ Because of the enormous expense of the hosting the games, it was highly improbable that he would have undertaken any two of the three offices of magistrate, president or curator annonae at the same time. This would narrow two of the famines down to early 51 and between late 52 and 54 .

What were the dates for the formation of the church in Corinth? The expulsion of the Jews by Claudius from Rome occurred AD 49. Paul's arrival is calculated as late 49 or early 50 and his ministry lasted 18 months, during the latter part of which the proconsul Gallio was appointed governor of Achaea. Gallio was to have held this office from 1 July, 51 for twelve months. Did he fulfill the office for the whole period? A note from his brother, Seneca, records that 'when, in Achaia, he began to feel feverish, he immediately took ship, claiming that it was not a malady of the body but of the place'. Pliny, in noting the hypochondria of Gallio, indicated that he needed a long sea voyage to recuperate after his consulship. Whether the Jews sought a decision against the Christians soon after he

${ }^{68}$ Wiseman, 'Rome and Corith I' 500 invokes West,Corinth 70 in support of his argument that 'It is not at all improbable that Dinippus's service was rendered during this time' and elsewhere places the date as $c$. AD 51.

${ }^{69}$ West, Corinth 52, AD 52-3 and Kent, Corinth 23-31, AD 57-8. The former's dating is based on A. Bagdikian, The Civic Officials of Roman Corinth (M.A. thesis, University of Vermont 1953).

$70 \mathrm{~A}$ census year was $51 / 52$. For the list of magistrates known to have held the office of magistrate and who issued local Corinthian coins bearing their name during the period, see $\mathrm{M}$. Amandry, Le monnayage des duovirs corinthiens $(\mathrm{BCH}$ Supp. XV, 1988) 76. As no coins were struck during of magistracy of Dinippus, the most likely date is $51 / 52$, contra Amandry, 74, n. 563 who follows K. M. T. Chrimes, Ancient Sparta: A Re-examination of the Evidence (Manchester University Press 1949) 183 n. 5 but without accounting for the presidency of the Games in 55. 
assumed office ${ }^{71}$ or Gallio remained in Achaea 'more than five months from June to the end of October', ${ }^{72}$ Paul's encounter with him may be placed between July and October AD 51. The period between his departure from Corinth and date of the writing of 1 Corinthians cannot be fixed precisely but late AD 53 or early 54 is feasible.

Clearly Dinippus was a leading Corinthian citizen and office-bearer during the early years of the church there. He could well have exercised the office of curator annonae once during Paul's stay in Corinth. The latter's concern not to be a burden to the church could have been related in part to the famine in the city. ${ }^{73}$

Precisely how Dinippus handled the food crises of Corinth is not known. He was obviously successful in his endeavours, for the leading citizens in the Council recorded their gratitude to him on behalf of the city. The ordinary citizens also expressed their thankfulness in their various Tribes for his crucial benefactions during the three tense periods of famine in Corinth. It is uncertain whether Dinippus handed out free grain as the size of the population must have been considerable. ${ }^{74}$ There is clear evidence that the emperor in a dire emergency did so in Rome. ${ }^{75}$ That all the Tribes of Corinth erected inscriptions identical to that of the Council of Corinth suggests that his benefactions were both timely and generous. More than that is not known from the archaeological evidence presently available. The important point to note is that food crises in Corinth were alleviated during the period of the early days of the church in the traditional way of the East by the curator of the grain supply.

${ }^{71}$ C. J. Hemer, 'Observations on Pauline Chronology', op. cit. 8 and The Book of Acts in the Setting of Hellenistic History (Tübingen, J. C. B. Mohr 1989) 251-3.

${ }^{72}$ Murphy-O'Connor, St Paul's Corinth:147 citing Seneca, Letters 104.1 and Pliny the Elder, Natural History 31.62 on his illness and Suetonius, Claudius 15 on his impulsive behaviour.

$73_{2}$ Cor. 11:9 in addition to the reason furnished in 1 Cor. 9:12.

${ }^{74}$ While estimates have been given of the population in ancient Corinth, the size of New Corinth cannot be determined for the first century from contemporary sources, J. Wiseman, The Land of Ancient Corinth, Studies in Mediterranean Archaeology 50 (Göteberg, P. Artiöms Förlag 1978) 11-12.

${ }^{75}$ Garnsey, Famine and Food 230. 
V. P. Furnish has commented 'Even when crops failed, Corinth's mercantile and commercial base must have provided the city with a substantial income. ${ }^{76}$ However the market needed to be manipulated and only then would the 'have-nots' have benefited from a decrease in the price of grain. The nonslave labourers and artisans who held Corinthian citizenship were most at risk. ${ }^{77}$ These were ordinary citizens who, in times of economic down turn, were most vulnerable. The slave and the freedman with links to a household were economically more secure than these citizens who were classified as of $\tau \iota \mu \eta$ EXovTes. The identity of this group is best understood from the comments of Euripides. He distinguished between two groups in the city. The first are the rich, whom he describes as useless and who are 'always lusting after more'. The second are designated as 'those who have not' and it is this group which

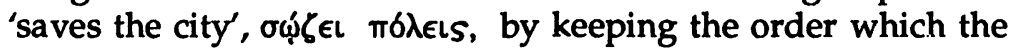
state ordains. They are contrasted with els tous Exyovtas, i.e. those who have riches and power as the ruling class and who seek for a public following from the second group..$^{78}$

The mechanism by which Corinth assisted the 'have nots' in times of grain shortage must have benefited that class mentioned by Paul in his enigmatic comments of 1 Corinthians 11.21, 33-4. It is clear that at the Lord's Supper in Corinth

76 Furnish, op. cit. 19. Hands, op. cit. 71 notes that when Athens in the fifth century was at the height of its prosperity the life of the ordinary citizen was one of 'extreme frugality' and that poverty was never eliminated during this period.

77 In Corinthian studies there has been a tendency to equate the rich and the poor of Corinth, and indeed the world of the first century, with the free born and the slaves, and thus to divide the whole of the society between the rich heads of houses who were free and the poor slaves who had nothing. In times of economic uncertainty it is clear that the slave had a security because of his place in the household. It is best to think in terms of the secure and insecure. The latter was a group vulnerable with steep rises in the price of food, and these were the non-slave artisans and labourers. On this group see P. Garnsey, 'Non-slave Labour in the Roman world', Non-Slave Labour in the GrecoRoman World (CPS Supp. 6; CUP 1980) 44-5 for a discussion of the selfemployed.

78 The Suppliant Woman 238-44. There is a third group whom he describes as extremely poor 'who are in want of life', omavlkovtes Blov. Hands, op. cit., 63 warns against over-generalizations drawing attention to the fact that one could classify himself as 'a beggar' in contrast to men of means even though he owned a plot of land. 
there were at least two economic groups represented. One group had food and drink. Among them were some who were drunk by the end of the proceedings. ${ }^{79}$ The 'have nots' are described as not only being hungry, $\pi \in(\nu \omega$, but also feeling a sense of shame. If this happened at the Lord's Supper within the context of a meal, then they were humiliated by the experience of waiting until others ate their meal, and subsequently joining with them in the drinking of the 'cup of blessing' immediately after the dinner was completed. ${ }^{80}$

The important question is precisely how Paul's solution helps those who are the 'have nots' in verses 33-4? The section begins with $\check{\sigma} \sigma \tau \epsilon$ and contains the imperative that if anyone is hungry, he must eat at home'. If the rich are being exhorted to eat at home because they are hungry in verse 34 , then the imperative is explicable because they would not cause the acute sense of shame felt by the 'have nots'. The injunction in verse 33a seems to take no account of the on-going needs of the poor. It is clear that the call 'to receive one another', i.e. welcome them, presumably means to share at the table rather than 'to wait for one another'. The latter meaning would not appear to resolve the matter for some are without food, for 'each one takes his own' according to v. 21. The resolution of the problem in the Lord's Supper is that there must be a sharing of that meal with those who are without food. ${ }^{81}$

How does Paul help the 'have nots' in the long term? It would seem that he proposes no immediate solution for their on-going economic plight, but is concerned in the letter only for their embarrassment at the Lord's Supper. If Corinth was

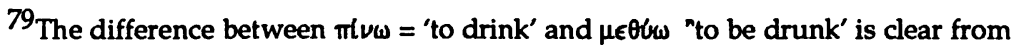

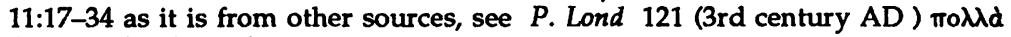

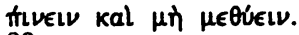

${ }^{80}$ Any reconstruction depends on the meaning of $\pi \rho \circ \lambda a \mu \beta a ́ v \in L \nu=$ simply to devour a meal' or 'to eat beforehand' and the aorist articular infinitive, $z \nu T Q$ $\phi a \gamma \epsilon l v$, where the reference is to the parameters within which $\pi \rho 0 \lambda \alpha \mu \beta \alpha v \in I \nu$ takes place. The latter verb when used in an eating context does not necessarily retain the temporal sense as in Athenaeus, Deipnosophistae III $84 c-85 a$, as epigraphic evidence clearly shows, SIG 31170 . The latter is noted by $M M$ in connection with 1 Cor. 11:21 where the translation suggested is 'everyone devours his own supper at the meal'; see also BAGD 2a. For detailed discussion see B. W. Winter, 'The Lord's Supper in Corinth: An Alternative Reconstruction', RTR 37 (1978) 73-82.

${ }^{81}$ Ibid. $79-80$. 
experiencing a grain shortage at this time, then the 'have nots' could have been given corn or have been able to purchase it however meagre an amount. The city guaranteed its own safety and civil order by rich benefactors safisfying the needs of the 'have nots'. As has been discussed, the benefactor who was curator annonae would have secured a reduction in the price of corn and would have made sure that the poor non-slave labourers and artisans had enough to subsist on in a time of shortage. Wealthy citizens as part of the community contributed financially and it has been argued that the early church encouraged Christians of substance to act as public bene-factors. ${ }^{82}$

It is not known what steps Paul would have taken in verse $34 \mathrm{~b}$ to remedy the situation when he promised 'and the

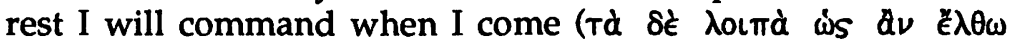

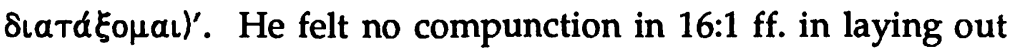
adequate procedures for the collection for the poor in Jerusalem. Why then was he reluctant to disclose his hand about the remaining matters in verse $34 \mathrm{~b}$ until he returned to Corinth? Did he anticipate some resistance to his plans for meeting the needs in Corinth, especially in the light of the divisions in the church in 11:18? What options would have been open to a Christian citizen in financial difficulty? For non-slave labourers and artisans there was the possiblity of support through the links of kinship and $\phi \perp \lambda l a$ with free loans which provided a safety net against starvation. As an alternative there was the personal patronage of the wealthy. ${ }^{83}$ Would Paul have had this in mind with the 'have nots'? Would a divided church have united to meet financial needs with a corn fund or interest free loans, given their conduct at the Lord's Supper? If the route of personal patronage was taken, would this not have further fuelled the divisions in the church along household lines with loyalties to leading patrons, for 'giving arid receiving' of money could thereby create a patron/client relationship ${ }^{84}$ Is it the case that the House of Stephanus ministered

${ }^{82}$ B. W. Winter, 'The Public Praising of Christian Benefactors: Romans 13.3-4 and 1 Peter 2.14-15', JSNT 34 (1988) 87-103.

${ }^{83}$ Garnsey, Food and Famine 80 .

${ }^{84} \mathrm{~S}$. C. Mott, 'The Power of Giving and Receiving: Reciprocity in Hellenistic Benevolence, in G. F. Hawthorne (ed.), Current Issues in Biblical and Patristic Interpretation: Studies in Honor of Merril C. Tenney (Grand Rapids, Eerdmans 
to the needy saints of Corinth during the famine either in cash or in kind? ${ }^{85}$ This 'ministering' may have been the solution Paul had in mind in 11:34, but his reluctance to set up such a mechanism for the whole church by letter may have been governed by the internal divisions which would only have been aggravated by such a move. The delay in establishing a churchwide mechanism in his absence is explicable, and the problem of idleness which occurred in Thessalonica through the abuse of providentia may have constituted another compelling reason, 2 Thessalonians 3:6-13.

\section{Responses of the Jerusalem and Corinthian Churches}

The church in Jerusalem from its very inception appears to have adopted the tested procedures of the synagogues in dealing with the food distribution, especially in relation to the widows. It is presumed it also used them in times of chronic food shortages. ${ }^{86}$ Every Friday in the synagogues distributions were made to the poor from the money chest. ${ }^{87}$ The Jerusalem church followed suit for the widows, but with a daily distribution as against the weekly one of the synagogue, a change perhaps governed by the former's daily corporate activity described in Acts 2:46.

Adjustments to this mechanism in the Jerusalem church were needed because the apostles, who initially assumed the identical role of the receivers and distributors of alms of the synagogues, drew sharp criticism from the Hellenists because of

1975) 60-72 esp. 63 the expression of gratitude placed a valid claim for further benefits upon the benefactor'. C. B. Welles, Royal Correspondence in the Hellenistic Period: A Study in Greek Epigraphy (New Haven, Yale University Press 1934) 108 comments in discussion of SIG 533 (218 BC) 'gratitude for one favour is the best method of securing another'.

$85_{1}$ Cor. 16:15-16. See A. Chapple, Local Leadership in the Pauline Churches: Theological and Social Factors in its Development: A Study based on 1 Thessalonians, 1 Corinthians, and Philippians (Ph.D. dissertation, University of Durham 1984) $403 \mathrm{ff}$ who suggests that the Stakovla of the House of Stephanus related to the poor and hospitality for the travellers.

${ }^{86} \mathrm{E}$. Schürer, op. cit., II 437 n. 45 who notes that the 'officers charged by the

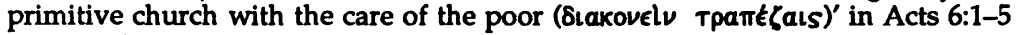
are fulfilling an identical role. See also B. W. Winter, 'Providentia for the Widows of 1 Timothy 5:3-16', TynB. 39 (1988) 88-90.

87 Schürer, op. cit. II 437. 
allegations of neglect of the latter's widows in this dis-

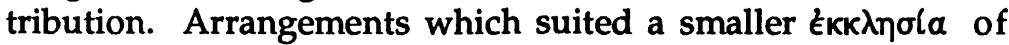
non-Hellenistic Jewish Christians apparently proved to be unsatisfactory with an increasing number of disciples in Jerusalem who included Hellenistic Christians and their widows, Acts 6:1a. The New Testament gives no hint that the mechanism for the distribution to the Christian poor in Jerusalem needed subsequent adjustments for the famine and Paul's collection from Greece. ${ }^{88}$

The Gentile Christians' response in their cities appears to have differed little from that of their fellow citizens. While their reaction to the famine crises was determined in principle by a particular eschatological perspective not shared by their non-Christian citizens, in practice the Corinthian church's resolution of the problem of food shortages appears to have been formulated by the existing secular mechanism used in times of shortages for helping the community in Greek cities. They would have waited for the appointment of a curator annonae to resolve the problem of the inflated price of grain. The wealthy Christian citizen would have been eligible to undertake secular offices in Corinth such as curator annonae. ${ }^{89}$

${ }^{88}$ The New Testament does however reveal that the problem continued to be a lack of resources from within the Jerusalem church. Only collections from the Diaspora Jewish and Gentile Christians saved them from destitution Acts 24:17 and 1 Cor. 16:1f., 2 Cor. 8-9 and Rom. 15:25-27, especially in the time of famine, Acts 11:27-30.

${ }^{89} \mathrm{Mr}$. A. Clarke, Tyndale House, Cambridge drew my attention to the third century grave stone of a Christian in Corinth who undertook the costly honorary office of aedile, Kent, Corinth no. 558, a position also held by Erastus who is referred to in Rom. 16:23, ibid. no. 232. While there has been some discussion as to whether the term olkovopos Paul used of the office Erastus held was the

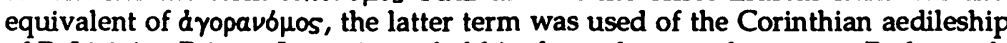
of P. Licinius Priscus Iuventianus held in the early second century. Both words are equivalents for the aedilis coloniae in the East, see H. J. Mason, Greek Terms for Roman Institutions - A Lexicon and Analysis, ASP 13 (1974) where he not only cites the inscription to Erastus but also IG Rom. 4 no. 1630 which records the various honours held by a sophist of Philadelphia which included $\delta \mathrm{Tis}$ $\pi \delta \lambda \epsilon \omega s$ olkóvouos. Election to this office was done under a well known convention called pollicitatio whereby the contending candidates made pledges i.e. election promises, and the pavement laid by Erastus was a fulfilment of such a promise. This was only part of the heavy financial undertaking for him in assuming the prestigous office of aedile in the illustrious Roman colony of Corinth. Although it is not possible to estimate the cost in Corinth, in North Africa there was a custom of levying a cost on various offices, and the amount 
Well-to-do members of the Corinthian church would have been expected as citizens to make financial contributions had the curator annonae established a corn fund, ${ }^{90}$ and thus 'do good to all men', Galatians 6:10a. It was the House of Stephanus which alone appears to have fulfilled the secular role of $\phi \backslash \lambda l a$ to needy individual Christians in a Christian spirit as a Pauline example of 'doing good...especially to those of the household of faith', Galatians 6:10b. Christians did 'take part in everything as citizens'. ${ }^{.1}$

levied on the aedileship varied according to the importance of the city, R. P. Duncan-Jones, 'Costs, Outlays and Summa Honorariai from Roman Africa', Papers of the British School at Rome 17 (1962) 103 no. 349-53a where the honour of the office of the aedileship varied from 20,000 H.S. for two cities to 4,000. Such payments were known in the East, P. Garnsey, 'Honorarium decurionatus', Historia 20 (1971) 325 citing examples, 325, n. 97. The office was next in rank to that of the magistrates and was third in status in Corinth, see West, Corinth no. $70,80-1,93,104 \mathrm{~b}, 132$; Kent, Corinth no. 152-156, 157, 164, 166, 168, et. al. for examples.

90 See my 'Public Honouring of Benefactors', op. cit.

${ }^{91}$ The extant evidence would appear to confirm this comment of the second century Christian writer of The Epistle to Diognetus V. 4-5, 8-9. 